\title{
Worker participation rights
}

Michel Coutu, Gilles Auzero and Isabelle Daugareilh

\section{(2) OpenEdition}

\section{Journals}

Electronic version

URL: https://journals.openedition.org/rdctss/1747

DOI: $10.4000 /$ rdctss. 1747

ISSN: 2262-9815

\section{Publisher}

Centre de droit comparé du travail et de la sécurité sociale

\section{Printed version}

Date of publication: 1 December 2018

Number of pages: 58-65

ISSN: 2117-4350

\section{Electronic reference}

Michel Coutu, Gilles Auzero and Isabelle Daugareilh, "Worker participation rights", Revue de droit comparé du travail et de la sécurité sociale [Online], 4 | 2018, Online since 01 November 2021, connection on 15 November 2021. URL: http://journals.openedition.org/rdctss/1747 ; DOI: https:// doi.org/10.4000/rdctss. 1747

Revue de droit comparé du travail et de la sécurité sociale est mise à disposition selon les termes de la Licence Creative Commons Attribution - Pas d'Utilisation Commerciale - Pas de Modification 4.0 International. 


\section{WORKER PARTICIPATION RIGHTS ${ }^{1}$}

\section{Michel COUTu}

Professor, University of Montréal, CRIMT

GiLles AUZERO

Professor, COMPTRASEC, University of Bordeaux

\section{ISABELLE DAUGAREILH}

CNRS, Research Director, COMPTRASEC, University of Bordeaux

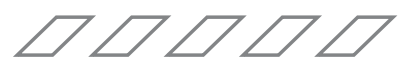

n a seminal book published in 1931, Le temps présent et l'idée de droitsocial, ${ }^{2}$ Georges Gurvitch highlighted the hitherto unseen development of worker participation in the management of companies. This new manifestation of social law was dealt with in two successive chapters, one devoted to the spectacular growth in collective labour agreements, the other to the emergence of "workers' control» per se. Taking his inspiration from the German doctrine in particular, primarily the works of Hugo Sinzheimer, ${ }^{3}$ Gurvitch emphasised that the new «labour constitution» (Arbeitsverfassung) ${ }^{4}$, by significantly

1 The articles in this publication are papers given at an international seminar organised jointly by the Interuniversity Research Center on Globalization and Work (CRIMT, Canada) and the Centre for Comparative Labour and Social Security Law (COMPTRASEC in Bordeaux on 22 and 23 September 2017. This seminar was held as part of the Better Institutions for Better Work Partnership Project international research project initiated by the CRIMT with the support of the Social Sciences and Humanities Research Council of Canada (SSHRC), in which COMPTRASEC is a participant: it had the support of the Universities of Paris-Dauphine, Bremen, Montreal and Louvain-La-Neuve (UCL). We wish to express our thanks for the scientific exchanges we had on that occasion with Gregor Murray and Philippe Barré (University of Montreal), Blanche Segrestin (MINES Paris Tech), Thierry Kirat (Paris-Dauphine University), Martine Le Friant (University of Avignon) and MarieAnge Moreau (COMPTRASEC). We also wish to express our gratitude for the contribution to the organisation of the seminar and the discussions made by the colleagues who participated by video link (simultaneously) at the University of Montreal, namely Nicolas Roby, Isabelle Martin and Francine Jacques

2 G. Gurvitch, Le temps présent et l'idée de droit social, Paris, Éditions du Recueil Sirey, Paris, 1931, sp.pp. 13-99.

3 H. Sinzheimer, Grundzüge des Arbeitsrechts, 2nd ed., Jena, Gustav Fischer, 1927, sp. pp. 207 et s.

4 To our knowledge, Max Weber was one of the first authors writing in German to make extensive use of the concept of «the labour constitution» in his quite remarkable early work on farmworkers in the east of Germany. See M. Weber, "Entwickelungstendenzen in der Lage der ostelbischen Landarbeiter«,1894, in Gesammelte Aufsätze zur Sozial- und Wirtschaftsgeschichte, Tübingen, J.C.B. Mohr, 1988, pp. 470-507. Already in Weber's work, the concept is more a sociological one than a legal one, whereas it is the opposite that would prevail when the concept was adopted into the Labour doctrine. 
limiting the previously unchallenged absolutism of the employer's right to manage, was an autonomous right, of an institutional rather than a contractual nature and one that was geared towards the democratisation of companies. For Gurvitch, this detaching of corporate management from ownership rights resulted either from the introduction of mandatory worker participation mechanisms (works councils: here Gurvitch gives the examples of Germany, Austria, etc.) or, more indirectly, from the enclosing of management rights within the dense regulations arising out of collective bargaining agreements (UK, United States).

Gurvitch, referring to French, Austrian and German authors, and above all Sinzheimer, on this subject, was starting from an institutionalist concept of the company, whereby the latter constituted within the capitalist economy an autonomous legal order, in fact a structure of domination subject from the outset to the absolutism of the employer. To counter arbitrary employer action and encourage the taking into consideration of the opposing interests of the workers, various forms of employee participation have been invented: the holding of shares, involvement in the organisation and management of the work and finally the presence of representatives within the company's governing bodies. For Gurvitch, some of these ideas are illusory or misleading: for example, participation in the capital, which risks tying the worker-shareholder to the company's economic ups and downs; likewise, the introduction by the employer of so-called representative committees which erect barriers to the presence of trade unions in the establishment. On the other hand, while the impact of co-determination in Germany remained to be measured, the introduction of works councils, guaranteed by Article 165 of the Weimar Constitution, a provision drafted by Sinzheimer, pointed to a possible way forward to ind ustrial democracy, the fruit of social self-determination, which was in no way in contradiction with trade union action and was also not a hijacking of autonomous social law by the State: on the contrary, through its necessary intervention, the latter was encouraging collective autonomy, without subordinating it in any way to the wishes of the State.

Several decades later, whereas in the meantime worker participation had seen a complete eclipse under the totalitarian regimes, then a significant renewal after the Second World War, in Germany first of all, and then in several European countries, without codetermination and co-management making any inroads in North America, the UK and the other English-speaking countries, Otto Kahn-Freund, also influenced by Sinzheimer, whose student he had been, wondered about the state of industrial democracy in Great Britain. ${ }^{5}$ The opportunity arose with the publication of the Bullock Report (1977) on this question, which recommended that the British parliament adopt a law obliging large companies to open their boards of directors to workers' representatives. Kahn-Freund was hostile to the idea, which no doubt contributed to the shelving of the report. From the structural point of view, he considered that in the absence of the indispensable infrastructure consisting of the prior existence of influential works councils, as is the case in Germany, this top-down introduction of a pinch of industrial democracy would lead nowhere. But, more fundamentally, Kahn-Freund was wondering what the logic behind all this fuss was, given that the strong presence of the British unions at establishment level imposed very significant constraints on employers, at least equivalent to, if not greater than those existing in Germany.

5 O. Kahn-Freund, «Industrial Democracy», Industrial Law Journal, 1977, Vol. 6, n 1, pp. 65-84. 
Regardless of what would come to pass later (failure of «collective laissez-faire» to resist the counter-reforms introduced by the Thatcher government), what should be retained from this comparative reading of Gurvitch and Otto Kahn-Freund is that the roads to worker participation are many, sometimes more symbolic than anything else, but frequently empirically effective, on the other hand. Furthermore, it is necessary to place these phenomena in their more general framework, taking account of the organisation of worker participation (in its wider sense) in the labour relations systems in question, depending in particular on whether they provide for an essentially monistic form of worker representation (collective bargaining conducted by representative unions) or a dualistic form (unions, works councils/co-management).

If we address the issue of worker participation from a social philosophy and philosophy of work angle, as suggested by Dominique Méda, looking at the broad picture of the ideas on worker self-organisation that prevailed from the second half of the $19^{\text {th }}$ century onwards in France, what is striking is the highly modern nature of the questions that were being asked at the time. The first reflections sought to overcome the workers' condition by means of producer associations, in cooperative or federalist ownership forms (Proudhon). At the turn of the century, associationism was defended by Jean Jaurès, but also by Adéodat Boissard, a French lawyer specialising in labour law. The latter spoke out against what he called "participationism», by which he meant the pseudo-participation of workers in companies' profits. The rationale behind this form of participation in the capital would logically include employees taking on management tasks and positions of authority, but of course this was refused to them. Even worse, dependent on economic and financial decisions over which they have no control, the workers find themselves stakeholders in the risks taken by their employer and liable to bear the brunt of the consequences.

Although with the progress made in collective bargaining and labour law, this idea of "participation-association» seemed for some time to have been set aside, it is periodically raised again and strongly advocated. For example, in 1985, political theorist Robert Dahl developed a strong critique of the authoritarianism that reigned in the economy, in particular in the United States, and argued in favour of the democratisation of the workplace. In particular he put forward the idea of a moral right to participate in economic decisionmaking, although he remained vague on how this participation would be implemented in concrete terms.

If we leave behind the theories of economic justice to consider the conditions of its implementation, at least four avenues can be identified: participative management in companies through the introduction of semi-autonomous work teams - which in no way alters the power structure; the formation of cooperatives as alternatives to the dominant entrepreneurial model - although in practice cooperatives mainly follow the same style of governance as capitalist enterprises; German-style co-management and codetermination, a model that has spread to a greater or less degree throughout Europe; and finally, direct worker participation in corporate governance, or what Isabelle Ferreras refers to as bicameralism.

Picking up these ideas from the angle of the sociology of labour relations and adopting a critical stance influenced by the work of Jürgen Habermas, among others, Isabelle Ferreras revisits T.H. Marshal's famous three-dimensional analysis of citizenship, linking the contribution of labour law to its social aspects. For Ferreras, fundamental labour rights, far from being secondary or derivative manifestations of social citizenship, should actually be associated with the sphere of political rights. Only this way of envisaging 
workers' participation rights adequately links economics and politics in a critical vision of contemporary democracies, in opposition to the perspective of liberalism which seeks to isolate the two spheres from each other. This has led to an obvious contradiction between democracy and capitalism and between citizens' aspirations for participation in the public space and the more and more extensive domination of social life by the economic actors. Now this contradiction makes itself felt acutely in companies, where employees seem to be «torn between the monopoly of power granted only to the investors of capital in their working lives and the aspiration for democratic equality». This fact means that there is a need to rethink the power structure in companies, with a view to making it more democratic. In this respect, Ferreras pleads in favour of institutionalisation, a system that goes beyond works councils and (in Germany) co-determination, beyond a mere space in the governance that represents the interests of the company's workers, through what she calls bicameralism.

Worker participation in the company is not only a political and social idea. It is also a right that has been enshrined in numerous legal systems, sometimes in fundamental laws, and in any case in diverse ways depending on the systems, and even within every system. The choice of the countries used to illustrate the different modes of worker participation first of all enables a critical approach to be taken to the models (Germany, Norway, Sweden) and, secondly, allows a graduated scale of the legal formulas chosen to be presented (Netherlands, France, Canada, Belgium), taking into consideration systems that have not gone beyond the stage of political aspiration (Belgium) as well as those that are pursuing this aim without fully achieving it (France). Wolfgang Däubler provides a reminder of how works councils originated in Germany: they appeared in the wake of the Councils movement that arose during the Revolution of November 1918, for which the Weimar Republic was to provide a constitutional basis. In 1947, the occupying powers favoured the re-introduction of co-management, with the support of the employers, who feared a socialisation of companies. To correctly grasp the current dynamics of co-management, it is necessary to take account of the dualistic model of governance that prevails in large companies (whether stock or limited liability companies) in Germany: in addition to the management board in charge of the day-to-day running of the company, there is also a supervisory board which supervises the former and validates certain decisions. Only the supervisory board is concerned by co-management.

This results in three possible cases: 1) in companies with between 500 and 2,000 employees, one third of the members of the supervisory board are elected by the workers; 2) when the company employs more than 2,000 workers, they elect half of the members of the supervisory board, although the chairman, who has the casting vote, is in practice always a representative of the shareholders; 3 ) finally, in the coal and steel sector, there is full parity between capital and labour in the supervisory board: the respective representatives of the employees and the shareholders jointly choose the chairman of the board and elect the members of the management board. By tacit arrangement, only the so-called «labour director» acts as the workers' representative.

In all cases, however, the room for manoeuvre of the workers' representatives is limited by the obligation of loyalty to the company, which in particular implies maintaining confidentiality. In addition, remarks Däubler, the workers' side often finds itself at a disadvantage due to a lack of information and expertise with respect to the complex issues discussed at supervisory board meetings. The problem can be particularly acute in the event of the restructuring of the company: in this area, collective bargaining, 
validated on this topic by the labour courts, offers more promising perspectives than co-management.

In a separate article, Christoph Teichmann and Justin Monsenepwo provide more information on this issue. With collective bargaining, co-management forms one of the two pillars of the German social partnership. The social philosophy behind it rests on the principle of balance and equality between the rights of labour and those of capital: it therefore seeks to compensate, in favour of the workers, for the dominance of the employers' wishes, which subsists in spite of the collective labour agreements and labour legislation. It is, however, important to distinguish between co-management in the establishment - the actual structure that applies in the workplace - which rests on the works council, and that exercised within the supervisory board, which depends on the legal form of the company itself. A works council must be set up in any workplace with at least five employees: co-management then extends to decisions concerning working conditions, such as working hours, overtime or working methods. As a result, the employer cannot take decisions concerning the collective management of the work without first obtaining the formal agreement of the works council.

As far as worker participation in the management of the company is concerned, the authors provide various clarifications relating to the strict separation between management and supervision in German company law. In particular this separation implies the limitation of the supervisory board's role solely to supervision and the impossibility of being a member of the management board and the supervisory board at the same time. In any event, as Teichmann et Monsenepwo emphasise, the dominant actors here remain the shareholders, which is in line with the constitutional guarantee of property rights arising out of the Basic Law. Whilst acknowledging that co-management ensures permanent social consultation at the top of the company and forms the basis of its legitimacy, the authors also observe that the rules are frequently circumvented by creating European or foreign subsidiaries and raise the question of a reform of the German co-management system.

Presenting the Nordic model of social dialogue, Bernard Johann Mulder highlights the essential element, which is trust - between the members and the leadership of the unions, but also between the social partners themselves, and finally between the latter and the government and administrative authorities. As everywhere, labour law developed in the wake of social unrest, but the acceptance of certain employers' prerogatives and the mutual recognition of trade unions and employers' associations has enabled cooperation to prevail. In addition, the State has allowed the social partners considerable latitude in the self-regulation of labour relations, recognising conciliation and arbitration and giving full legal value to collective labour agreements, which has fostered high union membership rates. For Mulder, the Nordic social model is characterised by the following elements: a high level of organisation of both employees and employers; the importance of collective labour agreements, which determine salaries and other working conditions; and finally, the limited role of the law compared to the position it holds in most European countries. Concerning this aspect, the author insists on the considerable influence exercised by the social partners on the content of the legislation. But this dimension is clearly relegated to second place by the fundamental importance of self-regulation, to the point where the author evokes, transposing the words of Otto Khan-Freund, a Nordic version of «collective laissez-faire» centred on collective bargaining.

The notion of democracy in the workplace, Mulder argues, implies a right for employees and unions to exercise significant influence on the employer's decisions. In both 
Norway and Sweden, worker participation in company supervisory boards is guaranteed by law.

Jan Cremers points out from the outset that in the Netherlands, the direct involvement of trade unions in companies remains modest, except at certain large employers. This is why works councils, required by law, have become the main channel for union representation at local level. The law obliges all companies with at least 50 employees to set up a works council, which has rights of information, consultation and co-determination. It should be noted that the consultation right particularly concerns the question of restructuring: in the event of a disagreement, the works council has a right of appeal before the Court of Appeal, which may block the decision in some cases. As for co-determination, this right concerns pensions, working hours, salaries and pay scales, reintegration policies, recruitment and other personnel-related policies.

The legislation also provides for workers' representation, in an indirect form however, on the supervisory board of companies with at least a hundred employees. Dutch companies in fact have a two-tier governance system, as in Germany, with a management board and a supervisory board. Here the works council plays a pivotal role, since in certain cases it may elect members of the supervisory board, although these members may not be employees. In practice, the experience has been mixed: unions and workers have not accorded very much importance to participation rights, which are in no way equivalent to those that exist in Germany, and have preferred to seek to reinforce the powers of works councils.

Examining both Belgian labour law and company law, Filip Dorssemont and Auriane Lamine highlight the refusal of the Belgian constituent power, in spite of economic, social and cultural rights being enshrined in the constitution in 1993, to give workers the right to participate in management, in contrast to the historically acquired rights enshrined in the French, Italian or German constitutions. The constituent power confined itself to guaranteeing only rights of consultation and information, which barely constituted any progress towards the democratisation of the workplace. In this respect, the authors distinguish co-determination from co-management. Whereas the former stands in the way of the unilateral adoption of decisions or rules by the head of the company, the second concerns the power to manage the company on a day-to-day basis.

Under Belgian law, any company employing at least 50 employees is obliged to set up a works council. The law also requires a health and safety committees (CPPT) and a trade union delegation (DS): only the latter is not a mixed body. These bodies intervene in the management's exercising of its regulatory, disciplinary and management powers. Accordingly, it is now the works council and no longer the head of the company that has the power to draft and amend the internal work rules. On the other hand, disciplinary power remains the preserve of the employer, although it is subject to the work rules. Finally, the power to manage is a corollary of the employer's entrepreneurial freedom and property rights. This means that restructuring plans cannot be challenged by workers, except from the point of view of their employment-related consequences. When it comes to management, the powers of the works council are limited in particular to matters concerning the organisation of work and the running of social schemes introduced by the company for the benefit of its employees.

Furthermore, under Belgian law, the interactions between labour law and company law remain limited. Only the role of the company auditor seems significant in this respect. Furthermore, company law does not impose any representation of the workers in the 
company's management body. Although economic democracy has featured among the demands of the Belgian trade unions for almost a century, no consensus has ever been found on how to achieve this objective.

On the other side of the Atlantic, in Quebec to be precise, Julie Bourgault and Michel Coutu consider that there would be little to say on this subject if we only took account of impact of collective bargaining. Indeed, Quebec law ignores the notion of dualistic representation (unions and works councils) which characterises most European labour relations systems. As advocated by the Wagner model, it is essentially through a highly decentralised system of collective bargaining, with state accreditation of only the majority union in a bargaining unit, that worker participation in the organisation of labour relations in companies takes place. Admittedly, the labour legislation does sometimes oblige companies to set up staff representative bodies, including in non-unionised sectors: for example, concerning health and safety at work or the redeployment of employees. However, where there is no trade union representation in the company, ${ }^{6}$ such committees seem to be devoid of any real effectiveness. Furthermore, it is extremely rare for workers to be able to sit on company boards, even if the Labour Code does briefly mention this as a possibility.

As far as unionised environments are concerned, the authors identify many weaknesses in the current system of collective bargaining in Quebec, starting with the lack of access to union membership of middle and junior managers, and so-called «entrepreneurs» who are in fact economically dependent employees. Likewise, the industrial peace obligation and the principle of majority support for the union as a sine qua non precondition of union representation also constitute substantial obstacles to full enjoyment of collective bargaining rights. In addition, Bourgault and Coutu highlight the frequent collision between collective bargaining and entrepreneurial freedom and property rights, fundamental (although unwritten) norms in the «economic constitution» in Canada. Thus, the anti-union closure of the Wal-Mart store in Jonquière in Quebec seemed to confirm the absolute primacy of these economic norms over the collective rights of workers. However, after an epic battle before the courts which dragged on for a decade, the 190 Wal-Mart Jonquière employees finally won their case and were awarded substantial compensation. This victory, at the very end of the road, before the Supreme Court of Canada, would be difficult to understand were it not for the reversal in the Court's case law, from 2007 onwards, concerning trade union freedom: a movement began at that time calling for the constitutionalisation of labour law, the precise contours of which still remain undefined, although, claiming from the outset to be seeking full compliance with international labour standards, they do contain the seeds of the possibility of an in-depth overhaul of Quebec's system of industrial relations and the worker representation and participation rights that go with it.

In France, worker participation in the management of companies rests on a constitutional basis, namely paragraph 8 of the Preamble to the Constitution of 1946, as Sylvain Niquège points out. So how is this principle applied in the large national enterprises in the public sector of the economy? The public sector does not refer in this respect to a specific legal form of company, and it may extend for example to semi-public companies (sociétés d'économie mixte). In any case, the essential question is whether the public sector is more favourable to worker participation than the private sector. Niquège observes that there is no participative model specific to large public sector enterprises. Under the French Labour Code, all

6 In Quebec, the union membership rate remains high compared to the rest of Canada and the United States, since it reaches $40 \%$ of the workforce. This rate has been stable for several years. 
companies, whether public or private, must meet the same requirements concerning worker participation, although this does not exclude some specific adaptations.

It is important to take account of the lack of a homogeneous status applicable to the staff of public enterprises. A hybrid situation exists, with the simultaneous presence of public employees of different categories (fonctionnaires, agents publics) and private law employees. For example, at France Télécom/Orange and La Poste, the transformation of the public entity into a commercial company has led to this kind of hybrid situation regarding the status of the employees. At La Poste, parliament chose not to introduce the participation arrangements provided for by the Labour Code, whilst authorising the election by all the workers, regardless of their status, of the members of the technical committee and the health, safety and working conditions committee. On the other hand, at France Télécom/Orange, the opposite option was chosen and the ordinary law on worker representation applies.

Asforthe private sector of the French economy, Gilles Auzero identifies two differenttypes of participation in management: co-management, which concerns the rules applicable to the representation of employees in the management bodies of the employer company; and co-determination, which suppose that certain decisions cannot be taken without the consent of the staff representatives. Until recently, French law showed little interest in either of these forms of participation. The works council, which has recently been renamed the "social and economic committee», ${ }^{7}$ essentially has only consultative attributions, except in certain matters: individualised working hours, appointment of the occupational health officer and internal redeployment of employees concerned by redundancy measures.

That said, certain changes are afoot in the French legal system. Regarding co-determination, the Labour Code provides that under a company or branch-wide collective agreement, the social and economic committee may be transformed into a "company council» (conseil d'entreprise) with more extensive prerogatives, in the field of training among other things. Initially, in 2013, they concerned co-management. However, Auzero warns «... all in all, the development of co-determination in our positive law has been abandoned to the wishes of the social partners, that is to say to an agreement between the employer and the employee unions. It is far from certain that the former will freely agree to give up a part of its decision-making powers.»

As for co-management, the Law on employment security of 14 June 2013 imposed the presence of employee representatives with voting rights on boards of directors and supervisory boards. This measure is limited to companies, subsidiaries included, that employ at least a thousand people. Furthermore, the Labour Code provides that the works council may delegate two of its members to attend board of directors and supervisory board meetings, in a consultative capacity. However, the author points out numerous shortcomings in French law in this area: for example, private limited companies (SARLs) and simplified joint stock companies (SASs), of which there are more and more, are not subject to the obligations on worker representation. In addition, the financialisation of the economy contributes to favouring shareholder governance of companies. Employees do not have access to the shareholders' general meeting, except indirectly (works council delegates) and can therefore only express themselves in a very marginal way.

7 The «social and economic committee» will be formed by merging the staff representatives (délégués du personnel), the works council (comité d'entreprise) and the health, safety and working conditions committee (comité d'hygiène, de sécurité et des conditions de travail). 